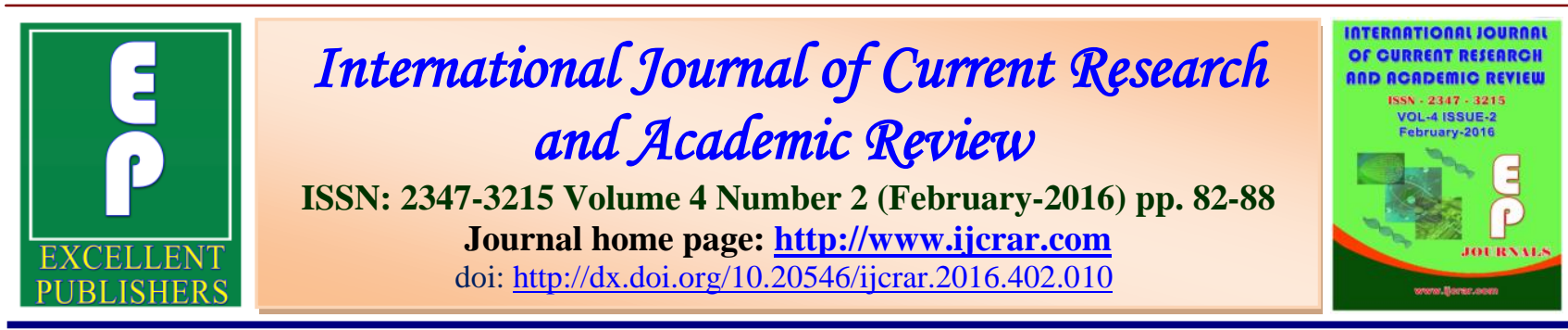

\title{
Aluminum Contents in Superficial Water of Great Rivers in the Littoral Region of Cameroon
}

\author{
Etoh Marie Annie ${ }^{1 *}$, Dina David J Daniel1, YinyangJacques ${ }^{2}$, Assokom O Eliane2, \\ Nguene Jean Pierre ${ }^{2}$ and Adiogo Dieudonné ${ }^{2}$
}

${ }^{1}$ Bio-organic, Structural and analytic laboratory, Faculty of Sciences, Douala University, Cameroon

${ }^{2}$ Faculty of Medicine and pharmaceutical Sciences -Douala University, Cameroon

\begin{tabular}{l|l}
\hline \multirow{2}{*}{$\begin{array}{l}\text { KEYWORDS } \\
\text { Rivers, water, }\end{array}$} & A B S T R A C T \\
$\begin{array}{l}\text { Dibamba, } \\
\text { Moungo, } \\
\text { Aluminum } \\
\text { content }\end{array}$ & $\begin{array}{l}\text { Cameroon has a great potential in mineral resources. In Douala, the } \\
\text { economic capital, there are many industrial activities which constitute sources } \\
\text { of diverse pollution, among these aluminum pollution, for its ubiquity and its } \\
\text { numerous uses. The city of Douala, main town of the littoral region of } \\
\text { Cameroon is surrounded by four rivers: the Sanaga rivers supplies the towns } \\
\text { of Edeand Douala with energy, and a great core industry of bauxite } \\
\text { processing in aluminum Alucam; the Wouri river with its numerous industrial } \\
\text { and harbour activities, Dibamba and Moungo rivers where fishing and sand- } \\
\text { digging are the main activities. The study of the assessment of aluminum } \\
\text { contents from these four rivers was made and it was found that the } \\
\text { concentration of aluminum was between 0.1 and 0.2 mg/L. It was also shown } \\
\text { that the presence of aluminum in these rivers is due to the deterioration of } \\
\text { rocks and soils; the streaming of waters, human activities, industrial waste } \\
\text { among others. These factors could be dangerous and hinder marine life. }\end{array}$
\end{tabular}

\section{Introduction}

Aluminum is the most important metal of the earth; it constitutes $8 \%$ of global earth volume. Due to its numerous characteristics, aluminum is used in various sectors such as industry, cosmetics, water processing ... the natural ubiquity of aluminum and its numerous uses are the factors that easily affect the population and the environment (Angerville et al. 2007; Jacqmin-Gadda et al. 1996). The natural degradations of rocks, the streaming of waters and human activities can be responsible of the presence of aluminum in the rivers. It can be found in various aspects: insoluble, soluble, ticked up together, corresponding to silicoaluminates, hydroxides, and many other complex forms mineral or organic (Angerville et al. 2007; Chassard-Bouchaud et al. 1992;Jacqmin-Gadda et al. 1996). 
Aluminum is more poisonous when soluble; environmental spread has many consequences: the presence of aluminum in the rivers is a factor of reduction of marine life; moreover, drinkable water from rivers should not be polluted beyond the level of $0.2 \mathrm{mg} / \mathrm{L}$, as recommended by the world health organization (WHO).

Cameroon is a developing country, rich in mineral resources. Douala, the economic capital and main town of littoral region is full of industrial activities which can enhance diverse pollutions, mainly aluminum pollution; Douala is surrounded by four rivers:Dibamba, Moungo,Sanaga and Wouri. These rivers flow into Guinea gulf and generate many industrial and hanbour activities.

Concerning the environmental conservation, our research aims at evaluating aluminum contents in rivers by means of a long-term and observative analysis.

\section{Materials and Methods}

\section{Sampling Sites}

The sampling took place in different places:

Sanaga River (figure 1), the longest in Cameroon, flowing all over the south side of adamaoua at the east side of West Mountains till the Bamboutos Mountains. It is made up of Lom and Djerem rivers, and flows into the sea.

On the downstream part of Edea town, Sanaga river flows into Guinea Gulf, its basin side is $140000 \mathrm{~km}^{2}$. It is a very important river in terms of hydro-electric energy. It supplies the towns of Edea and Douala and the great and powerful bauxite processing industry in aluminum, Alucam.

Wouri (figure 2)is the main river in the south west and flows all over the south side of the towns in west region of Cameroun. It is made up of Nkam and Makombe rives. Its basin side is $11500 \mathrm{~km}^{2}$. Here, there are many processing industries and harbor activities.

Dibamba river (figure 3) is made up of Ebo and Ekem rivers and Dibamba itself. The surface of its basin side is $2700 \mathrm{~km}^{2}$ activities in the rive are sand-digging and fishing.

Moungoriver (figure 4) rises at the north side of Koupe mountain. It is a low scale river with a sharp scape in its upstream but less steep from its border. It flows down in Guinea Gulf together with Wouririve through a huge and large delta; its side is $4000 \mathrm{~km}^{2}$. The activities are fishing and sand-digging.

All these four rivers flow all around the town of Douala and its vicinity, they flow down into Guinea Gulf.

\section{Chemical Analysis}

Before any sampling, very particular measures were taken. The bottles were first washed with nitric acid $10 \%$ and then with distilled water and labeled. At the beginning of the sampling exercise, the bottles were rinsed out several times with the water of the river. The sampling process took place in two different phases; the first concerned the Dibamba, Moungo, and Wouri rivers where waters are calm and untroubled; here, canoes were used. The second concerned the Sanagariver where waters are troubled because of current, the sampling process was done on the river banks.

By this method, many samples were taken from these four rivers :Sanaga (S1,S2,S3,S4); Dibamba (D1, D2, D3, D4, D5, D6, D7, D8); Moungo (M1, M2, M3, M4, M5, M6, M7, M8, M9, M10); Wouri (W1, W2, W3, W4, W5, W6, W7). 
The Microquant method with chromazurol S (Aluminum Microquant test of Merck, series number 1. 183 86. 0001) was used as technical analysis to measure the amounts of aluminum in each sample. This spectrophotometrical method gives approximatively the aluminum amount in the environmental medium.

\section{Results and Discussion}

From the four rivers flowing in the surroundings of Douala town, we took 30 samples. From the analysis of water, we recorded the following results (see Table 1). We took four samplings from Sanaga River, at the level of the dam; two samples from upstream and the two others from downstream. The concentration in aluminum is not detectable from upstream sample inferior to the one from downstream which is detectable (Table1). Samples from Dibamba (Table2), Mungo (Table3)and Wouri (Table4) rivers have a detectable aluminum concentration.

The observation of the results on Tables 1 to 4 showed thatthere is a dense volume of aluminum concentration in all the water from the great rivers of the littoral region. 28 samples out of 30 contained aluminum at various concentrations within 0.1 to 0.2 $\mathrm{mg} / \mathrm{L}$. In other words, $93 \%$ of samples from these rivers have a detectable aluminum concentration.

$50 \%$ of samples from Sanagariver had analuminum concentration inferior to 0.1 $\mathrm{mg} / \mathrm{L}$ and $50 \%$ concentration within 0.1 and $0.2 \mathrm{mg} / \mathrm{L}$ (Table 1). Considering the fact that samples were taken downstream and upstream of the dam and the fact that there is an aluminum processing industry (alucam) downstream of the dam, taking into account various communicating issues and exchanges existing between the soil and water it appears that the aluminum processing company is responsible of the presence of aluminum in that milieu, since there is no aluminum concentrations upstream the dam.

Meanwhile, there is aluminum in water down-stream. These are many factors which could explain the presence of aluminum downstream the dam: the soil; the company; the flowing of water transporting aluminum stocked upstream (considering that the current of water is too slow downstream, these for, entrance the stockage and consequently, the increase of aluminum concentration in that area.

Table.1 Aluminum Concentration in Sanagariver

\begin{tabular}{|c|c|c|c|}
\hline Sample sites & $\begin{array}{c}\text { Sample site } \\
\text { code }\end{array}$ & $\begin{array}{c}\text { Aluminium } \\
\text { concentration (mg/l) }\end{array}$ & \multicolumn{2}{|c|}{ Conclusion } \\
\hline Dyke (upstream) & $\mathrm{S} 1$ & $<0,1$ & $\mathrm{ND}^{1}$ \\
\hline Site 2 (upstream) & $\mathrm{S} 2$ & $<0,1$ & $\mathrm{ND}^{1}$ \\
\hline Bridgesite 1 (downstream) & $\mathrm{S} 3$ & {$[0.1 ; 0.2[$} & Presence of aluminum \\
\hline $\begin{array}{c}\text { Bridge site 2 } \\
\text { (downstream) }\end{array}$ & $\mathrm{S} 4$ & {$[0.1 ; 0.2[$} & Presence of aluminum \\
\hline
\end{tabular}

1. Not detectableMicroquant 
Int.J.Curr.Res.Aca.Rev.2016; 4(2): 82-88

Table.2 Aluminum Concentration in Dibambariver

\begin{tabular}{|c|c|c|c|}
\hline Sample sites & Sample site code & $\begin{array}{c}\text { Aluminium } \\
\text { concentration }(\mathbf{m g} / \mathbf{l}\end{array}$ & Conclusion \\
\hline Site 1 & D1 & {$[0.1 ; 0.2[$} & Presence of aluminum \\
\hline Site 2 & D2 & {$[0.1 ; 0.2[$} & Presence of aluminum \\
\hline Site 3 & D3 & {$[0.1 ; 0.2[$} & Presence of aluminum \\
\hline Site 4 & D4 & {$[0.1 ; 0.2[$} & Presence of aluminum \\
\hline Site 5 & D5 & {$[0.1 ; 0.2[$} & Presence of aluminum \\
\hline Site 6 & D6 & {$[0.1 ; 0.2[$} & Presence of aluminum \\
\hline Site 7 & D7 & {$[0.1 ; 0.2[$} & Presence of aluminum \\
\hline Site 8 & D8 & {$[0.1 ; 0.2[$} & Presence of aluminum \\
\hline Site 9 & D9 & {$[0.1 ; 0.2[$} & Presence of aluminum \\
\hline
\end{tabular}

Table.3 Aluminum Concentration in Moungoriver

\begin{tabular}{|c|c|c|c|}
\hline Sample sites & Sample site code & $\begin{array}{c}\text { Aluminium } \\
\text { concentration } \\
(\mathrm{mg} / \mathbf{l})\end{array}$ & Conclusion \\
\hline Bank 1 & M1 & {$[0.1 ; 0.2[$} & $\begin{array}{l}\text { Presence of } \\
\text { aluminum }\end{array}$ \\
\hline Bank 2 & M2 & {$[0.1 ; 0.2[$} & $\begin{array}{l}\text { Presence of } \\
\text { aluminum }\end{array}$ \\
\hline Medium 1 & M3 & {$[0.1 ; 0.2[$} & $\begin{array}{c}\text { Presence of } \\
\text { aluminum }\end{array}$ \\
\hline Medium 2 & M4 & {$[0.1 ; 0.2[$} & $\begin{array}{c}\text { Presence of } \\
\text { aluminum }\end{array}$ \\
\hline Medium 3 & M5 & {$[0.1 ; 0.2[$} & $\begin{array}{c}\text { Presence of } \\
\text { aluminum }\end{array}$ \\
\hline Bank 1' & M6 & {$[0.1 ; 0.2[$} & $\begin{array}{l}\text { Presence of } \\
\text { aluminum }\end{array}$ \\
\hline Bank 2' & M7 & {$[0.1 ; 0.2[$} & $\begin{array}{l}\text { Presence of } \\
\text { aluminum }\end{array}$ \\
\hline Medium 1' & M8 & {$[0.1 ; 0.2[$} & $\begin{array}{l}\text { Presence of } \\
\text { aluminum }\end{array}$ \\
\hline Medium 2' & M9 & {$[0.1 ; 0.2[$} & $\begin{array}{l}\text { Presence of } \\
\text { aluminum }\end{array}$ \\
\hline Medium 3' & M10 & {$[0.1 ; 0.2[$} & $\begin{array}{l}\text { Presence of } \\
\text { aluminum }\end{array}$ \\
\hline
\end{tabular}


Int.J.Curr.Res.Aca.Rev.2016; 4(2): 82-88

Table.4 Aluminum Concentration in Wouririver

\begin{tabular}{|c|c|c|c|}
\hline Sample sites & Sample site code & $\begin{array}{c}\text { Aluminium } \\
\text { concentration } \\
(\mathbf{m g} / \mathbf{l})\end{array}$ & Conclusion \\
\hline Bank 1 & W1 & {$[0.1 ; 0.2[$} & $\begin{array}{l}\text { Presence of } \\
\text { aluminum }\end{array}$ \\
\hline Bank 2 & W2 & {$[0.1 ; 0.2[$} & $\begin{array}{l}\text { Presence of } \\
\text { aluminum }\end{array}$ \\
\hline Medium 1 & W3 & {$[0.1 ; 0.2[$} & $\begin{array}{l}\text { Presence of } \\
\text { aluminum }\end{array}$ \\
\hline Medium 2 & W4 & {$[0.1 ; 0.2[$} & $\begin{array}{l}\text { Presence of } \\
\text { aluminum }\end{array}$ \\
\hline Medium 3 & W5 & {$[0.1 ; 0.2[$} & $\begin{array}{l}\text { Presence of } \\
\text { aluminum }\end{array}$ \\
\hline Bank 1' & W6 & {$[0.1 ; 0.2[$} & $\begin{array}{l}\text { Presence of } \\
\text { aluminum }\end{array}$ \\
\hline Bank 2' & W7 & {$[0.1 ; 0.2[$} & $\begin{array}{l}\text { Presence of } \\
\text { aluminum }\end{array}$ \\
\hline
\end{tabular}

Figure.1 Sanaga River (Google Earth, 2013)

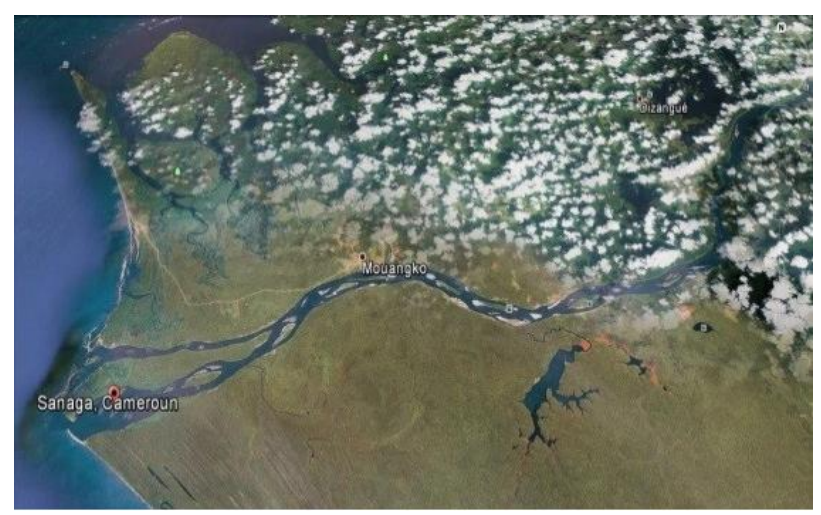

Figure.2 Wouririver (Google Earth, 2013)

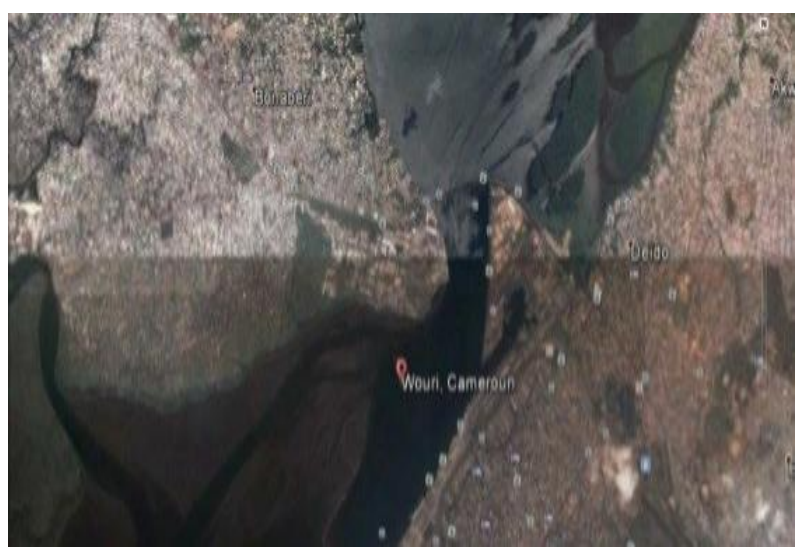


Figure.3 Dibamba River (Google Earth, 2013)

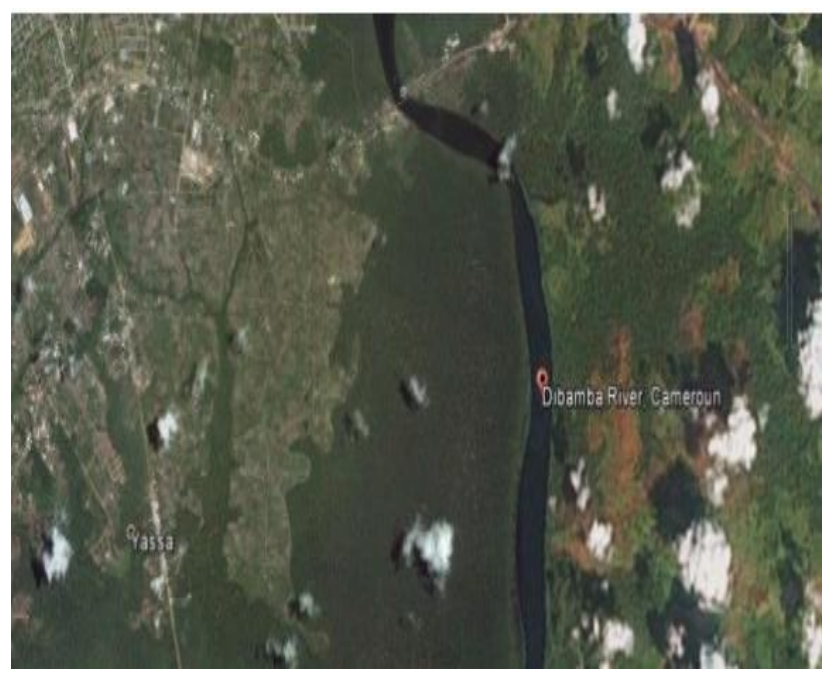

Figure.4 Moungo River (Google Earth, 2013)

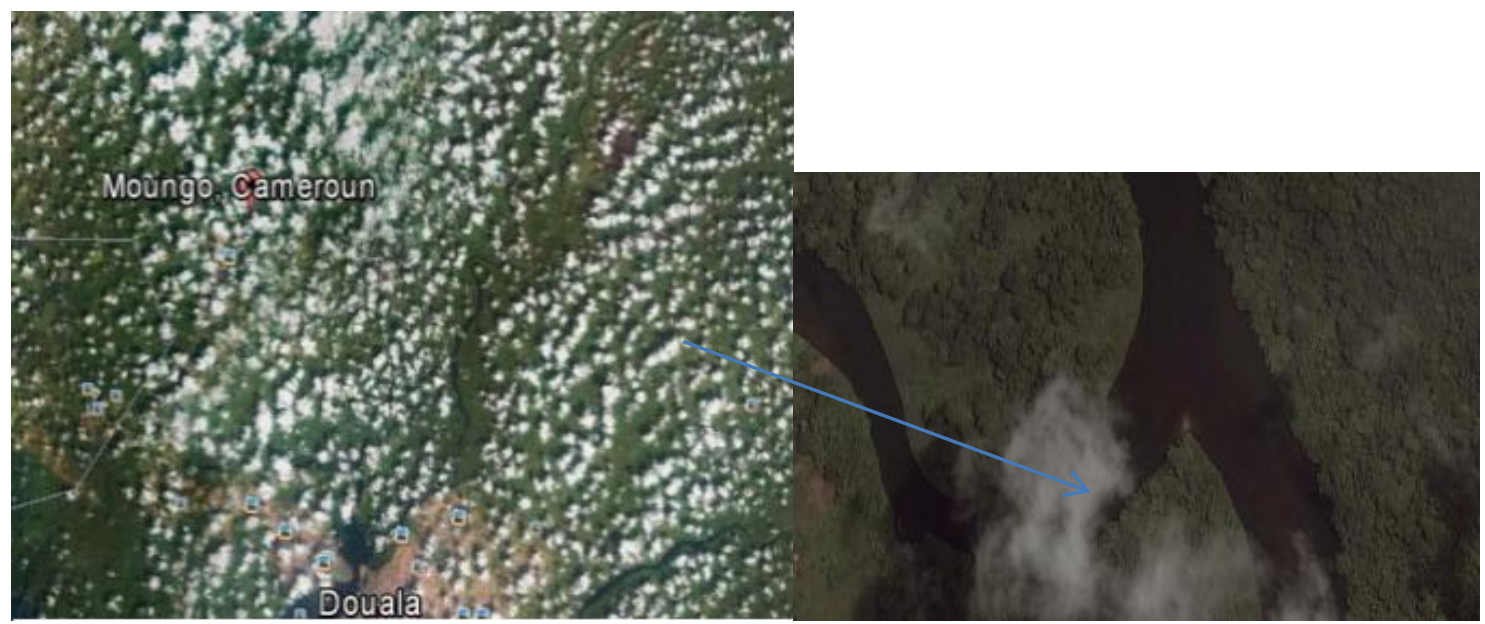

$100 \%$ of samplings from Dibamba and Moungo rivers contain aluminum (Tables 2 and 3), both their concentrations is within 0.1 and $0.2 \mathrm{mg} / \mathrm{L}$. During soil degradation, aluminum is easily movable; it appears that aluminum comes from the soil, from waste waters and from tide coming out.

All the samples from Wouririver (Table 4) contain aluminum, and the concentration is within 0.1 and $0.2 \mathrm{mg} / \mathrm{L}$. Aluminum may come from the soil, human activities particularly waste industrial waters. Thrown wastes are usually mixed up with poisonous products of different kinds (organic or nonorganic). Their presence and concentration depend on the pollution source.

Aluminum from water is biologically assimilated, and therefore becomes poisonous for fish (Chassard-Bouchaud et al. 1992; Poleo 1995) it is one of the main factors responsible of fish mortality (Dupont 2004; Probst 1992). Metals stocked in these waters contaminate human beings by direct consumptions or through the consumptions of poisonous organisms such as fish (BashirFathiet al. 2012). 
Aluminum from rivers of the littoral region could be one of the factors responsible for the decrease of marine life. It is important to know the characteristics of aluminum in order to understand the effects and asses the risks (Bérubé et al. 1999).

\section{Conclusion}

There is aluminum in the rivers of the littoral region, considering the ubiquity of aluminum (found everywhere), it would be important to further studies concerning poisonous sources and the effects on marine life and aquatic vegetation by studying the specificities of aluminum.

\section{References}

Jacqmin-Gadda, H., Commenges, D., Letenneur, L. and Dartigues, J. F. (1996). Silica and Aluminium in Drinking Water and cognitive impairment in the elderly. Epidemiology. 7(3), 281-285.

Angerville, R., Evens, E., andPerrodin, Y. (2007). Impact écotoxique potentiel sur les milieux récepteurs aquatiques des métaux en mélange dans les eaux pluviales urbaines. Novatech, 7(1), 1343-50.

Chassard-Bouchaud, C., Galle, C. H. and Lopez-Rabereau, E. (1992). Bioaccumulation d'aluminium chez la truite Salmotruttafario soumise aux retombées des pluies acides : étude structurale, ultrastructurale et microanalytique.Rev. Sc. Eau, 5, 3754.

PoleoA.B.S. (1995). Aluminum polymerization - a mechanism of acute toxicity of aqueous aluminum to fish.Aquatic Toxicology, 31, 347-356.

Probst, A. (1992). Dégradation de la qualité des eaux de surface $\left(\mathrm{NO}_{3}, \mathrm{Al} \ldots\right)$, Les recherches en France sur les écosystèmes forestiers. Office National des Forêts Edition, Fontainebleau, 67.

Dupont, J. (2004). La problématique des lacs acides au Québec. State Environmental suivi Direction, EnvironmentalMinister,envirodoqn

ENV/2004/0151, Collection $n$ QE/145, 18.

Alhashmi, B. F.,Shuhaimi-Othman, M. and Mazlan, A. G. (2012). Evaluation of TraceMetal Levels in Tissues of Two Commercial Fish Species in Kapar and Mersing Coastal Waters, PeninsularMalaysia. Journal of Environmental and Public Health,2012; 10.

Bérubé, D. and Brûlé, D.G. (1999). A field aluminum speciation method for study the aluminum hazard in water. Fresenius J. Anal. Chem., 363, 566-70.

\section{How to cite this article:}

Etoh Marie Annie, Dina David J Daniel, Yinyang Jacques, Assokom O Eliane, Nguene Jean Pierre and Adiogo Dieudonné. 2016. Aluminum Contents in Superficial Water of Great Rivers in the Littoral Region of Cameroon. Int.J.Curr.Res.Aca.Rev. 4(2): 82-88.

doi: http://dx.doi.org/10.20546/ijcrar.2016.402.010 